\title{
Revisiting the Null Subject Parameter: New Insights from Afro-Peruvian Spanish*
}

\author{
Sandro Sessarego \\ University of Texas at Austin / Freiburg Institute for Advanced Studies \\ sandrosessarego@yahoo.it \\ Javier Gutiérrez-Rexach ${ }^{\dagger}$ \\ Ohio State University \\ gutier@gmail.com
}

Received: $15-09-15$

Accepted: 15-12-16

\begin{abstract}
With the advent of the Minimalist Program (Chomsky 1995), the prevailing view on linguistic variation and contrast within universal Grammar has undergone a shift from rigidly defined parameters - associated with clusters of properties (Chomsky 1981; Chomsky \& Lasnik 1993) - to an approach in which features play a central role, are flexibly distributed, and originate in the lexicon, according to what Baker (2008) calls the "Borer-Chomsky conjecture" (Borer 1984; Chomsky 2001). A closer crosslinguistic look at empirical data seems to support this change in focus. The Null Subject Parameter (NSP) (Chomsky 1981; Rizzi 1982), as originally formulated, had a number of shortcomings (cf. Huang 1994; Holmberg 2005).

Within the realm of Spanish and Portuguese, two dialects that do not follow the predictions of the NSP are Dominican Spanish (DS) and Brazilian Portuguese (BP). The analysis of these varieties has led to the postulation of new hypotheses to account for their unexpected syntactic patterns (cf. Duarte 1993; Toribio 2000; Camacho 2008; etc.). The present study pays attention to yet another dialect of Spanish that does not conform to the NSP, Chinchano Spanish (CS), an Afro-Hispanic variety spoken in Chincha, Peru. In so doing, this paper provides an analysis of null and overt subjects that partially deviates from previous accounts of similar pro-drop phenomena.
\end{abstract} * We would like to thank the Freiburg Institute for Advanced Studies and the Marie
Skłodowska-Curie Junior Fellowship program for supporting this research. 
Additionally, this study proposes a model of contact-induced language transmission that explains why $\mathrm{CS}$ - as well as many other Afro-Hispanic languages of the Americas (AHLAs) - presents patterns that do not align this dialect with either null-subject languages (NSLs) like Italian or non-null-subject languages (NNSLs) like English.

Keywords: Afro-Chinchano Spanish, Null Subject Parameter, Pro-Drop Phenomena

\title{
Table of Contents
}

\author{
1. Introduction \\ 4. On the origin of Chincha Spanish \\ 2. The Null Subject Parameter (NSP) \\ 3. A look at two "partial pro-drop \\ partial pro-drop system \\ systems" in Romance \\ 5. The proposal \\ 6. Conclusion \\ References
}

\section{Introduction}

This article focuses on a set of syntactic phenomena, which have been related to the Null Subject Parameter (NSP) (Chomsky 1981; Rizzi 1982), and that can be found in Chinchano Spanish (CS), an Afro-Hispanic dialect spoken in the Province of Ica, coastal Peru: a) the presence of non-emphatic, non-contrastive overt pronominal subjects; b) an impoverished verb-agreement paradigm; and c) presence of non-inverted questions. The existence of such patterns in a number of Afro-Hispanic languages has traditionally been ascribed to their supposed creole origin (cf. Perl \& Schwegler 1998). The present analysis suggests that these structures can be accounted for as the result of conventionalized advanced SLA strategies, which do not necessarily imply any previous creole stage (cf. Sessarego 2013a). Additionally, a closer analysis of these phenomena in CS will provide new fuel for the debate on the current status of the Null Subject Parameter (NSP), the validity of its original predictions - rooted in the Principles and Parameters (P\&P) framework (Chomsky \& Lasnik 1993) — and possible adjustments within the research agenda put forward by the Minimalist Program (MP) (Chomsky 1995, 2001, et seq.; Boeckx 2011).

This paper consists of six sections. Section 2 briefly summarizes the original P\&P assumptions in relation to the NSP. Section 3 presents data from two Romance dialects that have generated much interest in recent years, since they do not appear to align either with null-subject languages (NSL) or with non-null subject ones (NNSL): Dominican Spanish (DS) and Brazilian Portuguese (BP). That section also offers an account of CS, another variety that acts as a semi-NSL. Section 4 consists of an account of contact-induced language transmission that may explain why CS, as well as several other Afro-Hispanic languages of the Americas (AHLAs), present the aforementioned syntactic features. Section 5 proposes a novel model to account for the data. Finally, section 6 discusses our results and concludes the study. 


\section{The Null Subject Parameter (NSP)}

Within the traditional Principles and Parameters (P\&P) approach (Chomsky 1981; Chomsky \& Lasnik 1993), languages can essentially be seen as the result of the interaction between the general principles of Universal Grammar, of an innate nature and shared by all language or linguistic varieties, and a finite set of binary parameters that are responsible for the syntactic variability observable across human languages. Within this framework, principles are "language-invariant statements" (Chomsky 1995: 25), whereas parameters must be set for certain values. Principles are part of an innate Universal Grammar (UG), which stems from our genetic endowment as members of the human species, i.e. the "language organ". As such, they do not need to be learned by exposure to language since they are hypothesized to precede specific acquisition processes. Rather, exposure to language merely triggers the parameters to adopt a certain setting. Dissimilar settings are associated with different languages (or varieties).

Chomsky (2000) uses an insightful metaphor when he compares the language faculty to a switch box or similar device. This box would consist of two components: a fixed network, which would represent the innate principles of language, and several switches, which are options determined by experience, representing binary parameters that can be set on or off. Divergent parametric combinations lead to different grammars. In Chomsky's (2000: 8) words:

When the switches are set one way, we have Swahili; when they are set another way, we have Japanese. Each possible human language is identified as a particular setting of the switches - a setting of parameters, in technical terminology.

The NSP has played a major role in the research agenda of generative grammarians for at least three decades. In fact, starting with the early work by Rizzi (1982) on null and overt subjects, as incorporated in the canonical works on the P\&P model (Chomsky 1981), this parameter has been taken as a good example of how apparently unrelated syntactic phenomena may be explained as the overt result of a single cluster of properties, all triggered by a particular setting of one "switch".

As recently summarized by Roberts \& Holmberg (2010: 16-18), an NSL, a language with a value [+] for the NSP, was expected to show the cluster of properties presented in (1-4), while an NNSL, a language with the value [-] for the NSP, was expected to lack them.

The possibility of a silent, referential, definite subject of finite clauses

a. Parla italiano.

(Italian, +NSP)

b. *Speaks Italian.

(English, -NSP)

'She speaks Italian.'

(2) Free subject inversion

a. Hanno telefonato molti student.

b. *Ont téléphoné beaucoup d'étudiants.

(Italian, +NSP)

'Many students have telephoned.'

(French, -NSP) 
Absence of complementizer-trace effects
a. Chi hai detto che - ha scritto questo libro?
(Italian, +NSP)
b. *Who did you say that - wrote this book?
'Who did you say wrote this book?'
(English, -NSP)

(4)

Rich agreement inflection on finite verbs

a. Yo como, tú comes, etc.

(Spanish, +NSP)

b. I eat, you eat, etc.

(English, -NSP)

Subsequently, as pointed out by Camacho (2008, 2013), other properties were attributed to +NSP languages: expletives must be null (5), and overt pronouns cannot take an arbitrary reading (6) (Suñer 1983; Jaeggli 1986) (6).

Expletives must be null
a. Llueve.
(Spanish, +NSP)
b. It rains.
(English, -NSP)

(6)

Overt pronouns cannot take an arbitrary reading

a. Dijeron que habían venido. (Specific or arbitrary reading)

b. Ellos dijeron que habían venido.

(Specific reading) 'They said that they had come.'

This latter generalization was formalized in Montalbetti's (1984) Overt Pronoun Constraint, which states that overt pronouns cannot be interpreted as a bound variable in a given language when such language has null pro, which is the element used for this type of dependent reading (7) (cf. Camacho 2008: 417-418).

\section{Overt-Pronoun Constraint}

a. Todo estudiantei cree que proi es inteligente.

b. Todo estudiantei cree que é 1 * $_{\mathrm{i} / \mathrm{j}}$ es inteligente 'Every student thinks that he is intelligent.'

The formulation of the NSP triggered a variety of empirical studies, which served as a testing ground for its predictions. The outcomes of that effort resulted in the reformulation and adjustment of the original proposal (i.e. Jayaseelan 1999; Tomioka 2003; Saito 2004; Holmberg 2005) and, in some cases, in its complete rejection (i.e. Newmeyer 2004; Haspelmath 2008). In fact, the study of a number of typologically different languages, in particular Asian languages (Vietnamese, Thai, and Japanese, etc.), showed that the NSP predictions did not hold cross-linguistically. For example, in Chinese, which is a language without verbal agreement, pronouns can be null if certain discourse requirements are met (cf. Huang 1994).

Without going as far as analyzing grammars with a high degree of typological distance from the languages originally studied by Rizzi (1982), it has been shown that, even within the realm of Romance, certain varieties present a mix of properties that appear to belong to both NSLs and NNSLs. Thus, their existence weakens the fundamental assumptions on which parametric syntax has been built in the sense of the binary character of parameters assumed by this theory. Such languages have often been labeled as "partial pro-drop systems" and, 
with the advent of the Minimalist Program (MP), new hypotheses have been proposed within the generative enterprise to account for them. Two such varieties are DS and BP, and the following section presents some of the main claims that have been made to analyze pro-drop phenomena in these systems.

\section{A look at two "partial pro-drop systems" in Romance}

One of the main theoretical shifts associated with the MP was a reassessment of the locus of cross-linguistic variation: from innate parameters - coming with clusters of properties - to features more freely distributed across the lexicon (Borer 1984). This prompted the formulation of new hypotheses rooted in the more cautious observation of the empirical evidence. DS and BP are two dialects that have generated much interest in relation to the NSP predictions, since neither of them appear to conform to properties traditionally ascribed to either nullsubject languages (NSLs) or non-null-subject ones (NNSLs).

Several studies have pointed out that non-emphatic, non-contrastive overt pronouns are extremely common in these languages to the point that many of the features traditionally differentiating null and overt pronouns in +NSP varieties appear to have been lost (Toribio 1993; Duarte 1995; Modesto 2000; Ordóñez \& Olarrea 2006; among others). In addition to the high rates of overt subjects, these languages also show a combination of properties that place them somehow in between NSLs and NNSLs. The half-way nature of these grammars has gained them the label of "partial pro-drop systems". Some studies have tried to account for the variation attested in these dialects by postulating that speakers of these varieties are somehow bilingual in their own language, thus they would be able to switch between +NSP and-NSP configurations within a single grammar (Toribio 2000), while others prefer to see the phenomena found in these dialects as the result of a change in progress, where NSL systems would be in the process of turning into NNSLs (Camacho 2008, 2013).

\subsection{Dominican Spanish}

Toribio (2000: 315-316) begins her well-known study on DS pro-drop phenomena by making a statement that is somehow symptomatic of the long-lasting academic clash between syntacticians and sociolinguists:

Linguistic theorizing, as carried out within the Principles and Parameters framework, has proceeded, to date, largely uninformed by pertinent facts revealed within the sub-discipline of dialectology. While the theory has been significantly articulated by reference to proposals regarding attested morphosyntactic differences between languages (e.g., Spanish versus English, or Spanish versus French), the study of syntactic variation as observed between and within dialects of the same language (e.g. Standard Latin American Spanish versus Dominican Spanish), with notable exception, has been relegated to the domain of sociolinguistics.

Toribio then proceeds to present the idiosyncrasies of DS in relation to the NSP. As can be observed in the following examples, DS presents a mix of constructions that are not supposed to be possible within a single language, if the 
NSP predictions really apply. Toribio points out widespread phonological processes of consonant deletion that provoke the weakening of verbal agreement (8); the coexistence of non-emphatic, non-contrastive overt subjects and null subjects (9); and the presence of overt expletive pronouns (10).

Verbal agreement weakening
a. Norm:
[sal.' tar], ['sal.tas],[sal.'ta.ßãn]
b. Santo Domingo: [sal.' tal], ['sal.ta], [sal.'ta.ßãy]
c. Cibao Valley: [saj.' 'taj], ['saj.ta], [saj. 'ta.ßãy]
d. Southern coast: [sar.' tar], ['sar.ta], [sar.' ta.ßãy]

(9) Coexistence of non-emphatic, non-contrastive overt subjects and null subjects

a. Si ellos me dicen que yo estoy en peligro cuando ellos me entren la if they CL tell that I am in danger when they CL enter the aguja por el ombligo yo me voy a ver en una situación needle through the belly-button I CL go to see in a situation de estrés.

of stress

'If they tell me that I am in danger when they put the needle in my belly-button, I am going to find myself in a stressful situation.'

b. Yo no lo vi, él estaba en Massachusetts, acababa de llegar...

I not it saw he was in Massachusetts finished of arrive

'I did not see him, he was in Massachusetts, he just arrived...'

(10) Overt expletive pronoun

a. Ello llegan guaguas hasta allá.

It arrive buses to there

'There arrive buses there.'

b. Ello había mucha gente.

it there were many people

'There were a lot of people on stand-by.'

Moreover, Toribio points out other phenomena that were not necessarily listed as properties deriving from a specific setting of the NSP, but which appear to be relevant to the analysis since they concern the use of pronouns: (11) lack of $\mathrm{S}-\mathrm{V}$ inversion in questions; ${ }^{2}$ (12) use of non-emphatic overt pronouns in pseudocleft constructions as questions; and (13) the use of structures with focalizing ser 'to be' (Bosque 1999; Camacho 2006; Méndez-Vallejo 2010).

2 Standard Spanish shows $\mathrm{S}-\mathrm{V}$ inversion in questions, which results in the following word order: wh-V-S. In CS, as well as in Caribbean Spanish, S-V inversion is not so systematic. For this reason, interrogative constructions of the type 'wh-S-V' are also allowed. 
(11) Lack of $S$-V inversion in questions

a. ¿Qué número tú anotaste?

what number you wrote

'What number did you write down?'

b. ¿Qué yo les voy a mandar a esos muchachos?

what I CL go to send to those boys

'What am I going to send to those boys?'

Pseudo-cleft constructions

a. ¿Dónde fue que tú estudiaste?

where was that you studied

'Where did you study?'

b. ¿En qué es que tú te vas a graduar?

in what is that you CL go to graduate

'What will you graduate in?'

Focalizing ser structures

a. Yo quiero es comida.'

I want is food

'I want food.'

b. Ese niño está es enfermo.

that child is is sick

'That child is sick.'

After reviewing these phenomena and the contexts in which they appear in DS, Toribio proposes an explanation for the observed patterns. She claims that DS is going through intensive grammatical restructuring, where linguistic parameters would be in the process of re-setting (2000: 328). She adopts several minimalist tenets (Chomsky 1995), such as the distinction between weak and strong features and Pollock's (1989) Split-Infl Hypothesis, according to which tense and agreement information is checked under two different nodes. In particular, her analysis focuses on the competition of morphological strengths of nominal features on the functional nodes TENSE and AGR. Since the verbal features contained in AGR and TENSE are supposed to be strong in Spanish, the verb must move to such nodes. AGR and TENSE are also responsible for checking the phi-features and Case features of subject NPs in their Spec positions.

Given that strong phi-features in AGR are needed to license null subjects (cf. Chomsky 1995), Toribio assumes that Standard Latin American Spanish AGR is endowed with them. Moreover, since in this dialect VSO word order co-exists with SVO in declarative constructions, she proposes a structure in which AGR is syntactically dominated by TENSE. On the other hand, given the intense process of grammatical restructuring in DS, AGR and TENSE would contain both strong and weak features. When AGR is endowed with weak nominal features, overt raising of NPs to Spec AGR would be prevented and-consequently-null subjects would not be allowed. In a similar fashion, when TENSE features are weak, only SVO constructions may occur, since VSO word order would be hampered. Thus in DS it would be possible to find the parameter setting represented by the properties of null subjects and postverbal subjects, as in 
Standard Latin American Spanish, as well as the innovative setting instantiated by lack of null subjects and presence of overt preverbal subjects.

Building on preceding studies on diachronic syntax (i.e. Kroch 1991; Roberts 1993), Toribio characterizes DS as a synchronic case of co-existing competing grammars (Roeper 1999; Yang 2002). Thus, DS speakers would have an I-language that is variable between parameter settings. From her point of view, therefore, DS speakers would be "bilinguals in their native language, acquiring two grammars with opposed, competing values for the relevant parameters" (Toribio 2000: 339), and thus the reason behind the variation attested in the data may be conceived as an alternation - or code-switch — between the two available grammars.

\subsection{Brazilian Portuguese}

More recently, Camacho $(2008,2013)$ summarizes a variety of studies on BP prodrop phenomena and points out patterns that do not follow the predictions of the NSP. In particular, building on Duarte's (1995) research, he highlights the fact that the rate of overt pronouns in BP has increased steadily during the last century so that it went from $20 \%$ in 1845 to $74 \%$ in 1992 . Such an increase in the use of overt pronouns parallels the erosion of the inflectional verb paradigm, as well as the reorganization of the pronominal system (see Tables 1 and 2) (Camacho 2008, adapted from Duarte 1995: 19; cf. also Kato \& Negrão 2000).

Table 1. Evolution of inflectional paradigms in BP

\begin{tabular}{|l|l|l|l|}
\hline Person/number & Paradigm 1 & Paradigm 2 & Paradigm 3 \\
\hline Speaker.sg & am-o & am-o & am-o \\
\hline \multirow{2}{*}{ Hearer.sg } & am-a-s & -- & -- \\
\cline { 2 - 4 } & am-a & am-a & am-a \\
\hline Other.sg. & am-a & am-a & am-a \\
\hline \multirow{2}{*}{ Speaker.pl } & am-a-mos & am-a-mos & -- \\
\cline { 2 - 4 } & -- & am-a & am-a \\
\hline \multirow{2}{*}{ Addressee.pl } & am-a-is & -- & -- \\
\hline & am-a-m & am-a-m & am-a-m \\
\hline Other.pl & am-a-m & am-a-m & am-a-m \\
\hline
\end{tabular}

Table 2. Evolution of the pronominal paradigm in BP

\begin{tabular}{|l|l|l|l|}
\hline Person/number & \multicolumn{2}{|l|}{ Pronoun } & Verbal ending \\
\hline Speaker.sg & Eu & Eu & am-o \\
\hline \multirow{2}{*}{ Adressee.sg } & Tu & \multirow{2}{*}{ Vocé } & am-a \\
\cline { 2 - 4 } & Vós & Ele/Ela & am-a \\
\hline Other.sg. & Ele/Ela & A gente & am-a \\
\hline Speaker.pl & Nós & \multirow{2}{*}{ Vocês } & am-a \\
\hline \multirow{2}{*}{ Addressee.pl } & Vós & & \\
\cline { 2 - 3 } & Vocês & Eles/Elas & am-a-m \\
\hline Other.pl & Eles/Elas & & \\
\hline
\end{tabular}

Since such a reduced verbal inflection is no longer able to satisfy the EPP, an overt (weak) pronoun must move to Spec IP to meet such a requirement. This 
would allow the use of subject clitic left dislocations (SCLLDs), as in (14) (cf. Barbosa, Kato \& Duarte 2005).

SCLLDs

a. A Clarinhai elai cozinha que é uma maravilha the Clarinha she cooks that is a marvel 'Clarinha, she cooks wonderfully.'

b. Então [o Instituto de Física]i elei manda os piores professores... then the Institute of Physics it sends the worst professors [Os melhores]j elesj dão aula no curso de matemática. the best they give class in the course of mathematics 'Then the Institute of Physics sends the worst professors ... The best teach in Mathematics.'

Moreover, as is well known, BP lacks the S-V inversion in questions commonly encountered in other Romance languages, and according to Duarte \& Kato (2002), this would be a change that took place in the $19^{\text {th }}$ century and correlates with the increase of overt pronouns (15).

$$
\begin{aligned}
& \text { Lack of } S \text { - } V \text { inversion (Silva 2001) } \\
& \text { a. O que a Maria leciona? } \\
& \text { what the Maria teaches } \\
& \text { 'What does Maria teach?' } \\
& \text { b. *O que leciona a Maria? } \\
& \text { what teaches the Maria } \\
& \text { c. Onde ela leciona? } \\
& \text { where she teaches } \\
& \text { 'Where does she teach?' } \\
& \text { d. *Onde leciona ela? } \\
& \text { where teaches she }
\end{aligned}
$$

As in the case of DS, in BP null and overt pronouns co-exist, and depending on the context, their interpretation may differ, as indicated by Modesto (2000: 152) and reported by Camacho (2013) (16). Thus, for example, the null subject in (16a) is obligatorily bound and does not display the 'standard' interpretive properties of pro (Holmberg et al 2009), while the pronoun in (16b) can be interpreted as referring to either Paulo (i), Pedro (j) or somebody else (k).

\section{Coexistence of overt and null pronouns}

a. O Paulo convenceu o Pedro $_{j}$ que pro $_{i / \mathrm{j} / \mathrm{k}}$ tinha que ir embora. the Poulo convinced the Pedro that had to go away 'Paulo convinced Pedro that he had to go away.'

b. O Paulo ${ }_{i}$ convenceu o Pedro que ele $_{i j / k}$ tinha que ir embora. the Poulo convinced the Pedro that he had to go away 'Paulo convinced Pedro that he had to go away.'

Interestingly, the high rates of overt pronouns also question the validity of Montalbetti's (1984) Overt Pronoun Constraint (OPC), since in BP both overt and 
null pronouns can be interpreted as bound variables (17) (cf. Barbosa, Kato \& Duarte 2005: 43, in Camacho 2013).

\section{Overt Pronoun Constraint violation}

a. [Ninguém no Brasil]i acha que elei é prejudicado pelo Governo.

'No one in Brazil thinks that he is harmed by the government.'

b. [Ninguém no Brasil $]_{\mathrm{i}}$ acha que pro $_{\mathrm{i}}$ é prejudicado pelo Governo.

After providing an overview of all these phenomena for $\mathrm{BP}$ - and contrasting them with those found in DS-Camacho concludes that these dialects should be seen as grammars in change. In particular, the author suggests that these varieties would be in the process of shifting from being NSLs to being NNSLs. Camacho (2008: 426) formalizes two possible paths of change, which we schematically reproduce in (18).

Two possible paths of change from NSL to NNSL

a. Higher frequency $\rightarrow$ [+/-ref] pronominal $\rightarrow$ Pronominal in Spec, IP $\rightarrow$ Pronominal satisfies EPP, becomes weak, infl becomes [ref]

b. Higher frequency $\rightarrow$ Pronominal in Spec, IP $\rightarrow$ Pronominal satisfies EPP, becomes weak, infl becomes [-ref] $\rightarrow$ pronominal [+/-ref]

In his view, in both (18a) and (18b) the main trigger of change is not inflectional erosion; rather, the main factor that would have set in motion this reorganization in the pronominal system would be the higher use of overt pronouns. The higher frequency of overt pronouns would lead to instances in which overt pronouns cannot be interpreted as emphatic/contrastive (19a). This would inevitably lead to a reanalysis of the bundle of features contained in either the pronoun or the inflection. If the pronoun is reinterpreted as non-referential [ref], then (19a) would be analyzed as (19b); on the other hand, if the inflection loses its referentiality, then the construction would be understood as (19c).

$$
\begin{array}{ll}
\text { a. } & \text { Él compra pan } \\
\text { he buys bread } \\
\text { 'He buys bread.' } \\
\text { b. Él compra pan } \\
\text { He buys bread } \\
\\
\text { c. }[- \text { ref }][+ \text { ref }] \\
\text { he bompra pan } \\
\text { he buys bread } \\
{[+ \text { ref }][- \text { ref }]}
\end{array}
$$

Camacho suggests that the unsystematic interpretation of overt pronouns as [+/-ref] results in their appearance in Spec IP; by doing so, they would both become weak and satisfy the EPP. In his view, the redundancy created by this new system, in which the EPP could be satisfied by both a weak pronoun and the inflection, may lead to a loss of inflectional referentiality. The aforementioned 
process would be depicted in (18a). However, the inverse path (18b) may also be an option. In this case, the overt pronoun would appear in Spec IP, thus it would become weak, satisfy the EPP and lead to a [-ref] infl, which would eventually lead to overt pronouns presenting [+/- ref] features.

\subsection{Chinchano Spanish}

We now wish to direct our attention to a different dialect of Spanish, CS, an AfroHispanic language spoken in Chincha, Peru, by the descendants of the slaves taken to this region to work on Jesuit sugarcane plantations during colonial times (cf. Sessarego 2014, 2015). The fieldwork for this study was carried out from November 2012 to January 2013 in the rural villages of El Guayabo, San José, San Regis and El Carmen, located in the Province of Chincha, Department of Ica, Peru. Some sixty informants of different ages participated in this study. Nevertheless, for the purpose of this paper we will only focus on the data collected for the eldest group, twelve speakers ranging between the 65 and 87 years of age.

$\mathrm{CS}$, in line with BP and DS, may be classified as a partial pro-drop system, in that structures that belong to NNSLs and NSLs are both attested. CS is a hybrid system, where overt subjects are used redundantly, without signaling either emphasis or contrast, as in example (20).

Non-emphatic, non-contrastive overt subjects

a. Mauricio fue también. Él se tomó una botella de cerveza y Mauricio went too. he CL drank a bottle of beer and después él se fue al bar de fiesta. after he CL went to the bar of party 'Mauricio went too. He drank a bottle of beer and afterwards he went to the bar to have fun.'

b. Cuando nosotros trabajamos, nosotros lo hacemos de verdá. when we work we CL do of truth 'When we work, we do it for real.'

Additionally, CS shows variable subject-verb agreement (21). In fact, third-person singular forms may appear as default forms, especially in the speech of the oldest informants. In some cases, the lack of verb inflection may be prompted by phonological processes of word-final consonant weakening $(21 \mathrm{a}, \mathrm{b})$ (cf. Sessarego 2015: ch. 4 for an overview of CS phonetics and phonology), while in other instances, the absence of verb inflection is clearly related to morphosyntax $(21 \mathrm{c}, \mathrm{d}){ }^{3}$

\section{Lack of agreement}

a. Ellas comía[n] lo que yo cocinaba. they ate CL that I cooked 'They ate what I cooked.' 
b. ¿Tú cree[s] que eso es así? you think that that is so 'Do you think that is like this?'

c. Yo compró un pedazo de tierra. I bought a piece of land 'I bought a piece of land.'

d. Nosotro vivía con poca plata. we lived with little money 'We used to live with little money.'

Our data from this dialect clearly indicate the presence of questions in which subject and verb have not been inverted (22a,b). Nevertheless, we wish to mention that not all questions present such a pattern; thus verb-inversion patterns are also attested in CS (22c,d).
Questions
a. ¿Cómo uté se lama? what you CL call
'What is your name?'
b. ¿Cuándo tú vuelve? when you return
'When are you coming back?'
c. ¿Qué quieres comer (tú)? what want eat you
'What do you want to eat?'
d. ¿Adónde van (ustedes)?
where go you
'Where are you going?'

CS also presents another property that has been ascribed to NNSLs: overt pronouns can take an arbitrary reading (23) (cf. Suñer 1983; Jaeggli 1986). Moreover, Montalbetti's (1984) Overt Pronoun Constraint (24) is not applying to CS.

\section{Overt pronouns can take an arbitrary reading}
a. Dijeron que habían venido. said that had come
(Specific or arbitrary reading)
b. Ellos dijeron que habían venido. (Specific or arbitrary reading) they said that had come
'They said that they had come.'

\section{Overt-Pronoun-Constraint violation}

a. Todo estudiantei cree que proi/j es inteligente. all student think that is intelligent

c. Todo estudiantei cree que él $\mathrm{l}_{\mathrm{j}} \mathrm{j}$ es inteligente all student think that he is intelligent 'Every student thinks that he is intelligent.' 


\section{On the origin of Chincha Spanish partial pro-drop system}

We would like to propose that CS, as well as several other Afro-Hispanic contact varieties, can be seen as the result of $L 1$ acquisition (nativization) of advanced L2 grammars (cf. Sessarego 2013a). The basic idea behind the nature of several Afro-Hispanic languages is that enslaved populations of African origin had relatively good access to Spanish (the target language, TL), which allowed them to achieve a certain degree of mastery in it. Thanks to UG, each individual internalized one grammar out of a set of possible grammars (G1, G2, Gn). Their linguistic outputs $(\mathrm{x}, \mathrm{y}, \mathrm{z})$ served as the primary linguistic data (PLD) for the following generation, who acquired this language natively. This model can be schematically represented in (25), where Grammar 1 (G1) and Grammar 2 (G2) represent two possible grammars with different parametric configurations:

a. Individual from Generation 1:

TLy $\rightarrow$ UG driving L2 acquisition $\rightarrow \mathrm{G} 1 \rightarrow$ set of outputs X

b. Individual from Generation 2:

PLDx $\rightarrow$ L2 driving L1 acquisition $\rightarrow \mathrm{G} 2 \rightarrow$ set of outputs $Z$

In this model, the L1 acquisition of Generation 2 represents the process of nativization. The result of this is an L1 grammar (G2), built on L2 inputs. G2, therefore, will present crystallized aspects of an L2, which are acquired as an L1.

This statement is based on the assumption that L1 and L2 acquisition are driven and constrained by Universal Grammar (UG). During childhood, first language acquisition develops naturally and instinctively - if the child is exposed to enough linguistic input. L2 development operates somewhat differently. L2 speakers have access to UG, but biological and social factors conspire against the full mastery of the target language (TL). In fact, the loss of spontaneity of acquisition and incomplete command of the L2 morpho-lexicon are two inevitable consequences of biological age maturation. Moreover, certain social aspects of L2 acquisition, such as lack of motivation, acculturation and free time, oftentimes contribute to the incomplete mastery of the L2 (Herschensohn 2000: ch.3).

Along these lines of reasoning, we wish to claim that the use of nonemphatic, non-contrastive overt subjects is a linguistic phenomenon related to the acquisition of the null-subject parameter (Chomsky 1981; Rizzi 1982). Subject expression in null-subject languages such as Italian or Peninsular Spanish requires a certain degree of maturation in the acquisition of several constraints operating at the syntax/pragmatics interface, since both structural and discourse-related features appear to be at play. As it has been observed, null subjects (pro) tend to be used in topic and non-contrastive focus contexts. The example in (26) illustrates the use of pro in Spanish (Montrul et al 2009: 303). In this case, pro expresses old information, in the sense that pronominal reference can be resolved from discourse. 
Juan llegó a su casa del trabajo. Primero pro se cambió de Juan arrived to his house from the work first CL changed of ropa y luego pro decidió ponerse a preparar la cena. clothes and then decided put himself to prepare the dinner 'Juan came home from work. First he changed his clothes and then he decided to make dinner.'

Generative studies on the acquisition of the NSP in L2 have consistently found an overproduction of overt subjects in contexts requiring the null realization of the pronoun in standard Spanish (White 1985, 1986; Phinney 1987). Recent research has uncovered evidence suggesting that even advanced L2 learners tend to produce a surplus of overt subject pronouns. The explanation would be that topic features are difficult to acquire and, consequently, a native-like use of overt and covert pronouns is not likely to obtain (Sorace 2000, 2003, 2004). In fact, according to Grimshaw \& Samek-Lodovici (1998), the difference between an overt subject and pro in a pro-drop language is the presence of a [+topic shift] feature in the former which would be absent in the latter. Such a distinction does not exist in non-pro-drop languages such as English, where all subject pronouns must be spelled out.

These hypotheses would be compatible with the proposal that some aspects of Afro-Hispanic contact varieties should be seen as advanced second language phenomena (Sessarego 2013a). The grammatically adequate and pragmatically felicitous use of pro in Spanish implies the simultaneous knowledge of interrelating syntactic and pragmatic properties. Consequently, the fact that non-emphatic, non-contrastive overt pronominal subjects are consistently attested in these languages would not be surprising, since they can be viewed as instantiations of nativized, advanced, second language grammars.

Another significant issue in the analysis of the acquisition of Spanish as a second language is the host of phenomena derived from the relative mastering of phi-features (person, gender, number). The morphological expression of these features can be mostly considered "redundant" in this language and does not contribute to semantic interpretation. The complete mastery of such a pattern of morphological expression occurs relatively late in L2 acquisition and oftentimes is not achieved at all (Franceschina 2002).

With respect to Spanish L2 grammars, the slow acquisition of agreement features results in Spanish interlanguages instantiating varying degrees of morphological incompleteness or departure from the standard variety in the marking of regularly agreeing expressions across the nominal and verbal domains. This property can be related to the well-attested observation that Spanish verb forms with invariant person and number are frequent in many L2 varieties of Spanish and also in child language (Bybee 1985). In all of these cases, the most common pattern is the use of the third-person singular form as the default one. The CS variety and the other AHLAs display variable levels of subject-verb (dis)agreement. These phenomena, in turn, reflect an aspect of their degree of restructuring (Sessarego 2012): in some varieties, third person singular default forms can be attested regularly (e.g., Afro-Bolivian Spanish, cf. Lipski 2008; Sessarego 2011), while in other varieties, they are more sporadic (e.g., Chota Valley Spanish, cf. Sessarego 2013b). 
The presence of non-inverted questions may also be ascribed to the nativization of advanced second language acquisition processes. In fact, while several formal approaches maintain that the presence/absence of subject-verb inversion may be linked to the existence of a parametrized interrogative feature strength $([+\mathrm{wh} / \mathrm{Q}])$ in $\mathrm{C}^{\circ}$, which would be difficult to acquire even in late L2 stages (Rizzi 1996; Cuza 2013; Guerra Rivera et al. 2015), linguistic theories that do not necessarily embrace the parametric/minimalist framework do acknowledge that subject-verb inversion is only mastered at advanced L2 levels of proficiency (cf. Pienemann 1998, 2005).

An anonymous reviewer has pointed out the possibility that the use of nonemphatic, non-constative overt subjects in CS may be seen as a case of retention of an archaic feature, rather than an instance of grammatical innovation. This hypothesis would be based on the assumption that in certain varieties of Medieval Romance overt subjects in dependent clauses were almost compulsory (Bennincà 1984; Adams 1987; Cagnola 2013, 2014).

While the idea of finding archaic patterns in Afro-Hispanic dialects may correctly explain the presence of certain morphosyntactic and phonological features in these varieties (cf. Sessarego 2015, 2017b), we think the use of overt pronouns in CS may be better analyzed as the result of contact-induced change. First, Benincà's and the other abovementioned studies were primarily based on Old French and Old Italian data, and as far as we know, evidence has yet to be provided to show that the Medieval Spanish pronominal system resembled what we observe today in CS. Second, the patterns of pronominal use detected for CS also appear to be in line with the phenomena encountered in a number of Spanish contact dialects and second language varieties (Lipski 1993; Montrul 2004), thus indicating that L2 acquisition/contact processes may be the real reason behind what we see in CS and many other Afro-Hispanic/creoloid vernaculars.

\section{The proposal}

When we take a close look at the CS data, the hypothesis of constant codeswitching (argued by Toribio for DS) appears to be counterintuitive for this dialect, since it is difficult to explain why monolingual speakers would keep code-switching between two supposedly parallel grammars. They are not exposed to different languages as, for example, in the case of Spanish-English code-switchers in the US. Thus, what we observe in CS is a typical case of internal language variation, not the alternation between two separate codes. An analysis in terms of the 'grammars in change' idea (cf. Camacho's proposal) is also insightful but needs supplementation.

We do acknowledge that - to a certain extent-at the social/community level all grammars are in constant change, but at least at the idiolectal level, based on the grammaticality judgments of our informants, we would like to pursue an explanation where some stability is assumed-in line with mainstream generative assumptions. This line of analysis is consistent with Embick's (2008) claims that the question of whether there is a sociolinguistic effect on the distribution of variants can be kept distinct from the study of the constructions under consideration.

If we adopt one of the main tenets of the Chomskyan view of grammar, there is a fixed inventory of computational mechanisms that are universal (the 
Universal Grammar hypothesis) and change or variation take place at a 'micro' level of analysis. One of the leading assumptions of the Minimalist Program is that such computational devices or operations are minimal and constant in nature (internal or external Merge, Agree). Differential outputs in linearization are the result of contrasting feature specifications in the lexical items involved (at the initial starting point for the computation or 'numeration'). Stating this differently, the hypothesis that we want to advocate is that we should approach the phenomena associated with a hybrid NSP system, such as CS, not as an instance of code-switching or evolving grammars, but as an instance of competing lexical and functional entries, à la Adger \& Smith (2005).

What this means is that, for a variety of reasons, the inventory or feature specification of lexical or functional elements differs not only across languages but also across varieties, making room for a more fine-grained treatment of sociolectal and idiolectal variation. More specifically, lexical or functional items with two possible specifications may coexist in a given variety. The choice of one or the other will have consequences in the word order arrangements that might become available.

An anonymous reviewer asks what would be the advantage of postulating variable lexical entries (our hypothesis) over code-switching (Toribio's model) or grammars in change (Camacho's proposal). We think the advantage of doing so is that we do not need to imagine the existence of competing grammars (coming with competing clusters of properties) in the speech of monolingual speakers. Rather, we just need to postulate variation in the selection of entries. The variable selection of one item over another may be affected by a number of external and internal factors (ease of lexical access, frequency, education, age, etc.) but syntax per se remains constant in our model (cf. also Brody 2003), given that variation is located only in the item selection during the numeration phase. As Adger \& Smith (2005: 164) point out, this is a very economical theory, "since the idea that speakers have to choose lexical items is one which we simply cannot do without."

Cases of variable subject-verb agreement can be formally captured by postulating that in these dialects two different Tense Heads (T) are potential candidates to enter the lexical numeration: T1 and T2 (cf. Adger \& Smith 2005 for a similar account for Buckie English). T1 bears tense, case, number and person features, like in standard Spanish, while T2 lacks number and person features. The result of the operation Agree (and Merge) between a subject pronoun and T1 will be a verb form conjugated for tense, number and person. On the other hand, the same operation involving $\mathrm{T} 2$ will result in a verb form conjugated for tense, but showing default features for number and person. These operations can be schematically represented for the verb bailar 'to dance' and the pronoun nosotros 'we'. Let us consider the derivation in (27) and the spell-out in (28) first:

(27) T1 [tense:present, $u$ case:nom, $u$ num:, $u$ pers:] ... pronoun [num:pl, pers:1, case:nom] $\rightarrow$ T1[tense:present, num:pl, pers:1] ....pronoun [num:pl, pers:1, case:nom]

$$
\begin{aligned}
& \text { Spell-Out: Nosotros bailamos } \\
& \text { We.NOM dance.PRESENT.I.PL }
\end{aligned}
$$


In this scenario, the merger of the tensed verb form with the pronoun and the application of Agree derives the agreement configuration that is standard in Latin American and Peninsular Spanish. Adopting the probe-goal model of syntactic computation (Chomsky 2000), the T head acts as a probe with unvalued features. Such features get valued by co-valuation or unification (Pollard \& Sag 2004) with the pronominal goal. Person and number features are valued by matching or co-valuation. Case is the feature that sets the goal as an active match and satisfies the EPP feature of the probe (Chomsky 2001). ${ }^{4}$

Let us now look at the alternative 'non-agreeing' configuration. In this alternative scenario, the probe is not specified for person and number. Thus, it targets the goal to satisfy its EPP (case) feature. Nevertheless, there is no covaluation with the person and number features of the goal (pronoun) because T2 is not specified for them. Thus, the agreement operation will not target such features of the pronoun. The system leads to default (third person singular) values of the goal (Sessarego \& Ferreira 2016). ${ }^{5}$

$$
\text { T2 [tense:present, } u \text { case:nom] ... pronoun [num:pl, pers: } 1, u \text { case:] } \rightarrow
$$
T2 [tense:present] ....pronoun [num:pl, pers:1, case:nom]

\section{Spell-Out: Nosotros baila \\ We.NOM dance.PRESENT.3.SG}

Along the same lines of reasoning, the alternation between non-emphatic overt subjects and null subjects may be explained as the result of a different selection of overt pronominal categories, which may or may not contain a [+topic shift] feature (cf. Grimshaw \& Samek-Lodovici 1998), thus leading to constructions like (20), which would sound pragmatically odd in standard Spanish. Therefore, we suggest that in CS it is possible to find-as in standard Spanish-categories such as pro (lacking the [+ topic shift] feature value), and overt pronouns (showing it), as well as overt pronouns that do not carry such a value, as in many advanced L2 and heritage varieties of Spanish (Rothman \& Slabakova 2011; Domínguez 2013). We illustrate this model by reproducing example (20b) under the form of (31), in which [+/- topic shift] feature values have been indicated.

Cuando nosotros trabajamos, nosotros lo hacemos de verdá. [+topic shift] [-topic shift]

'When we work, we do it for real.'

$4 \quad$ Subject-oriented EPP is not always put together with Case. Subject-oriented EPP can be a D-feature on T (Chomsky 1995) or it can be the need for a Specifier of T (Chomsky 2001). As such, it is independent of Case. Accounts that put together the EPP and Case as two sides of the same coin in general try to eliminate the EPP in favor of obligatory Case assignment (cf. Ortega-Santos (2008) for some discussion on these EPP issues in Spanish).

Similar but yet different accounts of impoverished agreement phenomena and default features may be encountered also in Halle \& Marantz (1994), Preminger (2014), Nunes (2011), etc. 
Let us now look at the well-attested phenomenon of lack of subject-verb inversion in interrogative environments. CS, in line with several other AfroHispanic dialects and with Caribbean Spanish varieties, allows for constructions in which a fronted $w h$-operator ( $w h$-op) - a $q u$-word or phrase in Spanish-is followed by preverbal subjects when the wh-operator is an argument (32), thus giving rise to both $w h-\mathrm{S}-\mathrm{V}$ and $w \mathrm{~h}-\mathrm{V}-\mathrm{S}$ questions.

Afro-Hispanic/ Caribbean varieties

a. ¿Qué tú comes?

what you eat

'What do you eat?'

b ¿Qué comes (tú)?

what eat you

'What do you eat?'

Conversely, wh-S-V constructions are not generally grammatical in Mainland Spanish dialects, so that only the $w h-\mathrm{V}-\mathrm{S}$ pattern is allowed (33).
Mainland Spanish
a. ¿QQué tú comes? what you eat
'What do you eat?'
what eat you
'What do you eat?'
b. ¿Qué comes (tú)?

The problem of subject inversion or lack thereof in questions has commanded much recent attention (summarized in Villa-García 2015), and, due to space constraints, we will not be analyzing it here. What is more relevant for our purposes is to focus on the connections with theories of Second Language Acquisition (SLA).

Within the generative SLA tradition, several studies have been carried out to understand how wh-movement and subject-verb inversion are acquired and to test whether UG is available during L2 development. The conclusions on the accessibility of UG during L2 acquisition have been variable but results have suggested that the mastery of such structures may be difficult to obtain, especially if the learner's L1 does not present such constructions (e.g., in Chinese, Korean, and Japanese) (cf. Johnson \& Newport 1989; Birdsong 1992; White 1992; Martohardjono \& Gair 1993; White \& Juffs 1998; among others).

Since the co-occurrence of fronted wh-operators and preverbal subjects is a common feature of Spanish creoles (cf. Holm \& Patrick 2007), a potential creole origin for the Spanish dialects showing this characteristic has often been suggested (Perl 1998). There are at least two facts that seem to weaken such a hypothesis. First, SLA studies have shown that non-inverted questions also appear cross-linguistically in very advanced stages of SLA (Pienemann 1998, 2005), thus indicating that they are not necessarily symptomatic of creoles. Second, it should be pointed out that while Afro-Hispanic and Caribbean varieties show wh-S-V constructions (cf. 32a), the $w h-V-S$ order is also commonly used (32b) and 
quantitative studies indicate that it is actually the most frequent one (cf. GutiérrezBravo 2008: 227) for DS. Nevertheless, traditionally, the analysis of Caribbean $w h-S-V$ interrogative constructions has been contrasted with the $w h-V-S$ structures found in Mainland Spanish. A recent account by Gutiérrez-Bravo (2005, 2007, 2008) stresses the importance of keeping in mind that (32a) and (33b) should not be analyzed as equivalent constructions in two different dialects; indeed, he shows that both of them co-exist in Caribbean Spanish and are based on different structures used in diverse pragmatic contexts. Conversely, in Mainland Spanish, (33a) is not a grammatical option. Its equivalent is (34), where the subject is a sentence topic displaced to the left-peripheral position.

$$
\begin{aligned}
& \text { Tú ¿qué comes? } \\
& \text { you what eat } \\
& \text { 'What do you eat?' }
\end{aligned}
$$

Gutiérrez-Bravo $(2005,2008)$ formulates the following Interrogative Clause Condition to explain the EPP requirement associated with interrogative clauses: A clausal Extended Projection is interrogative if the head of the highest phrase in the Extended Projection bears the feature [Q].

After formulating this condition, Gutiérrez-Bravo claims that in sequences like (33b), TP is the highest projection, wh-op lands in [Spec, T], and $\mathrm{T}^{\circ}$ acquires a [Q] feature from Spec-Head agreement with the $w h$-op. The presence of $w h$-op in [Spec, T] satisfies the EPP requirement instantiated by such a position, so that the subject remains in its VP internal position, as shown in (35). On the other hand, in (32a), the wh-operator lands in [Spec, C] so that $\mathrm{C}^{\circ}$ acquires its [Q] feature. Since [Spec, T] is empty, a topicalized subject will be able to land there and satisfy the EPP requirement, as shown in (36).

$$
\begin{aligned}
& \text { [те Quée comes [vр tú } \left.\left.t_{j} t_{i}\right]\right] ? \\
& \text { wh } T^{\circ} \\
& {[Q] \rightarrow[Q]} \\
& {\left[C P \text { Quéi } \varnothing\left[\text { TP túj comesk }\left[V P \text { t t t } t_{i}\right]\right] ?\right.} \\
& \text { wh } C^{\circ} \\
& {[Q] \rightarrow[Q]}
\end{aligned}
$$

\section{Conclusions}

In this paper, we have presented an analysis of pro-drop phenomena in CS, an Afro-Peruvian dialect, in which a mixed system is attested with respect to the NSP. This dialect, in line with DS and BP, exhibits a partial pro-drop grammar.

An account of these facts is problematic for a standard view of parameters based on the idea/metaphor of a switchboard with several on/off switches. More recent accounts, in terms of hypothesizing changing or competing grammars, although representing an improvement over the fixed-parameters idea, are somewhat inadequate to characterize what is going on in CS, and potentially also in other dialects. Thus, in this paper we have argued that the mastery of overt and null 
pronouns, verbal agreement and inverted questions depends on advanced acquisition strategies, which appear to be hampered by processability and language interface constraints (e.g., syntax/pragmatics and syntax/morphology interfaces).

In line with Minimalist constructionist assumptions (Herschensohn 2000), the acquisition of the lexicon and of its formal features (Borer 1984) is supposed to develop gradually through a UG-driven path, and the differential specification of certain functional elements (in our case $\mathrm{T}$ ) seems to play a pivotal role. This process generates several possible L2 grammars, with different parametric configurations. The variable second language learners' output resulting from this acquisition process represents the PLD of the following generation, which will nativize the language into a new grammar. In general, this paper also provides evidence for arguments questioning the validity of the NSP or, more broadly, for recent proposals that revisit the concept of 'parameter' and suggest new potential paths of analysis (cf. Boeckx 2011).

\section{References}

Adams, Marianne. 1987. Old French, Null Subjects and Verb Second Phenomena. Doctoral dissertation. UCLA.

Adger, David and Jennifer Smith 2005. "Variation and the minimalist program". In Leonie Cornips and Karen P. Corrigan (eds.), Syntax and Variation. Reconciling the Biological and the Social, 149-178. Amsterdam: John Benjamins. http://dx.doi.org/10.1075/cilt.265.10adg.

Baker, Mark. 2008. The Syntax of Agreement and Concord. Cambridge: Cambridge University Press. http://dx.doi.org/10.1017/cbo9780511619830.

Barbosa, Pilar, Maria Eugênia Duarte and Mary A. Kato. 2005. "Null subjects in European and Brazilian Portuguese". Journal of Portuguese Linguistics 4: $11-52$. http://dx.doi.org/10.5334/jpl.158.

Benincà, Paola. 1984. "Un'ipotesi sulla sintassi delle lingue romanze medievali". Quaderni Patavini di Linguistica 4: 3-19.

Birdsong, David. 1992. "Ultimate attainment in second language acquisition". Language 68: 706-755.

http://dx.doi.org/10.1353/lan.1992.0035.

Boeckx, Cedric. 2011. "Approaching Parameters from below”. In Anna Maria di Sciulloand Cedric Boeckx (eds.), The Biolinguistics Enterprise: New perspectives on the evolution of the human language faculty, 205-221. Oxford: Oxford University Press.

Borer, Hagit. 1984. Parametric syntax. Case studies in Semitic and Romance Languages. Dordrecht: Foris.

Bosque, Ignacio. 1999. "On focus vs. wh-movement; the case of caribbean Spanish". Sophia linguistica 44-45: 1-32.

Brody, Michael. 2003. Lexico-logical form. Cambridge, MA: MIT Press.

Bybee, Joan. 1985. Morphology: A Study of the Relation between Meaning and Form. Amsterdam: John Benjamins. http://dx.doi.org/10.1075/tsl.9. 
Camacho, José. 2006. "In situ focus in Caribbean Spanish". Proceedings of the 9th HLS, 12-23.

Camacho, José. 2008. "Syntactic variation: the case of Spanish and Portuguese subjects". Studies in Hispanic and Lusophone Linguistics 1 (2): 415-433. http://dx.doi.org/10.1515/shll-2008-1027

Camacho, José. 2013. Null subjects. Cambridge: Cambridge University Press. http://dx.doi.org/10.1017/cbo9781139524407.

Cognola, Federica. 2013. Syntactic Variation and Verb Second. A German Dialect in Northern Italy. Amsterdam/Philadelphia: John Benjamins. http://dx.doi.org/10.1075/la.201.

Cognola, Federica. 2014. "On asymmetric PRO-DROP in Mòcheno. Pinning down the role of contact in the maintenance of a root-embedded asymmetry". Stuf - Language Typology and Universals- Sprachtypologie und Universalienforschung 67 (4): 511-532.

http://dx.doi.org/10.1515/stuf-2014-0027.

Cuza, Alejandro. 2013. "Crosslinguistic influence at the syntax proper: interrogative subject-verb inversion in heritage Spanish". International Journal of Bilingualism 17: 71-96. http://dx.doi.org/10.1177/1367006911432619.

Chomsky, Noam. 1981. Lectures on Government and Binding. Dordrecht: Foris. http://dx.doi.org/10.1515/9783110884166.

Chomsky, Noam. 1995. The Minimalist Program. Cambridge, Mass.: MIT Press. http://dx.doi.org/10.7551/mitpress/9780262527347.001.0001.

Chomsky, Noam. 2000. "Minimalist Inquiries: The framework”. In Roger Martin, David Michaels and Juan Uriagereka (eds), Step by Step: Essays on Minimalist Syntax in Honor of Howard Lasnik, 89-156. Cambridge, Mass: MIT Press.

Chomsky, Noam. 2001. “Derivation by Phase”. In Michael Kenstowicz (ed.), Ken Hale: A life in language, 1-52. Cambridge, Mass: MIT Press.

Chomsky, Noam and Howard Lasnik 1993. "The theory of principles and parameters". In Joachim Jacobs, Arnim von Stechow, Wolfgang Sternefeld, and Theo Vennemann (eds.), Syntax: An international handbook of contemporary research, Vol. 1, 506-569. Berlin: Walter de Gruyter.

Domínguez, Laura. 2013. Understanding Interfaces. Amsterdam: John Benjamins.

Duarte, Maria Eugênia. 1993. "Do pronome nulo ao pronome pleno: A trajetória do sujeito no português do Brazil”. In Ian Roberts and Mary A. Kato (eds.), Português brasileiro: uma viagem diacrônica, 107-128. Campinas: Ed. Da Unicamp.

Duarte, Maria Eugênia. 1995. "A perda do princípio 'Evite pronome' no português brasileiro". Doctoral Dissertation. UNICAMP.

Duarte, Maria Eugênia. and Mary A. Kato. 2002. "A Diachronic Analysis of Brazilian Portuguese WH-Questions". Santa Barbara Portuguese Studies 6: 326-340.

Embick, David. 2008. "Variation and morphosyntactic theory: competition fractioned". Language and Linguistics Compass 2: 59-78.

Franceschina, Florencia. 2002. "Case and $\varphi$-feature agreement in advanced L2 Spanish grammars". EUROSLA Yearbook 2: 71-86. 
http://dx.doi.org/10.1075/eurosla.2.07fra.

Guerra Rivera, Alexia, Peter Coopmans and Sergio Baauw 2015. "On the L2 acquisition of Spanish subject-verb inversion". Procedia - Social and Behavioral Sciences 173: 37-42.

http://dx.doi.org/10.1016/j.sbspro.2015.02.027.

Grimshaw, Jane and Vieri Samek-Lodovici 1998. "Optimal subjects and subject universals". In Pilar Barbosa, Danny Fox, Paul Hagstrom, Martha Jo McGinnis and David Pesetsky (eds.), Is the best good enough? Optimality and competition in syntax, 192-219. Cambridge, MA: MIT Press.

Gutiérrez-Bravo, Rodrigo. 2005. Structural Markedness and Syntactic Structure. New York: Routlegde/Taylor and Francis. http://dx.doi.org/10.4324/9780203959602.

Gutiérrez-Bravo, Rodrigo. 2007. "Prominence scales and unmarked word order in Spanish". Natural Language and Linguistic Theory 25: 235-271. http://dx.doi.org/10.1007/s11049-006-9012-7.

Gutiérrez-Bravo, Rodrigo. 2008. "Topicalization and preverbal subjects in Spanish wh-interrogatives". In Joyce Bruhn de Garavito and Elena Valenzuela (eds.), Selected Proceedings of the 10th Hispanic Linguistics Symposium, 225-236 Somerville, MA: Cascadilla Proceedings Project.

Halle, Morris and Alec Marantz 1994. "Some Key Features of Distributed Morphology". In Andrew Carnie, Heidi Harley (eds.), Papers on Phonology and Morphology, 275-288. Cambridge, Mass: MIT

Haspelmath, Martin. 2008. "Parametric versus functional explanations of syntactic universals". In Theresa Biberauer (ed.), The limits of syntactic variation, 75-107. Amsterdam: Benjamins.

http://dx.doi.org/10.1075/la.132.04has.

Herschensohn, Julia Rogers. 2000. The Second Time around: Minimalism and L2 Acquisition. Amsterdam: John Benjamins. http://dx.doi.org/10.1075/lald.21.

Holm, John A. and Peter L. Patrick (eds.). 2007. Comparative Creole Syntax. Parallel Outlines of 18 Creole Grammars. London: Battlebridge.

Holmberg, Anders. 2005. "Is there a little pro? Evidence from Finnish". Linguistic Inquiry 36: 533-564.

Holmberg, Anders, Aarti Nayudu and Michelle Sheehan. 2009. "Three Partial Null-Subject Languages: A Comparison of Brazilian Portuguese, Finnish and Marathi". Studia Linguistica 63: 59-97.

http://dx.doi.org/10.1111/j.1467-9582.2008.01154.x.

Huang, Yan. 1994. The syntax and pragmatics of anaphora: a study with special reference to Chinese. Cambridge: Cambridge University Press.

Jaeggli, Osvaldo. 1986. "Arbitrary plural pronouns". Natural Language and Linguistic Theory 4: 43-76.

Jayaseelan, Karattuparambil. A. 1999. "Empty pronouns in Dravidian". In K. A. Jayaseelan (ed.), Parametric studies in Malayalam syntax, 14-25. New Delhi: Allied Publishers.

Johnson, Jacqueline S. and Elissa L. Newport. 1989. "Critical period effects in second language learning: The influence of maturational state on acquisition of English as a second language". Cognitive Psychology 21: 60-99. http://dx.doi.org/10.1016/0010-0285(89)90003-0. 
Kato, Mary and Esmeralda Negrão (eds.). 2000. Brazilian Portuguese and the Null Subject Parameter. Frankfurt and Madrid: Vervuert/Iberoamericana.

Kroch, Anthony. 1991. "Reflexes of grammar in patterns of language change". Language Variation and Change 1: 199-244. http://dx.doi.org/10.1017/s0954394500000168.

Lipski, John. 1993. "Creoloid Phenomena in the Spanish of Transitional Bilinguals". In John Lipski and Ana Roca (eds.), Spanish in the United States: Linguistic Contact and Diversity, 155-182. Berlin: Mouton de Gruyter. http://dx.doi.org/10.1515/9783110804973.155.

Lipski, John. 2008. Afro-Bolivian Spanish. Madrid/Frankfurt: Iberoamericana/Vervuert. http://dx.doi.org/10.1075/cll.32.12lip.

Martohardjono, Gita and James W. Gair. 1993. "Apparent UG inaccessibility in SLA: Misapplied principles or principled misapplications?" In Fred R. Eckman (ed.), Conference: Linguistics, Second Language Acquisition and Speech Pathology, 79-103. Amsterdam: John Benjamins. http://dx.doi.org/10.1075/lald.4.08mar.

Méndez-Vallejo, Catalina. 2010. "Syntactic variation in Colombian Spanish. The case of the Focalizing Ser (FS) structure". In Sonia Colina, Antxon Olarrea and Ana Maria Carvalho (eds.), Romance Linguistics 2009: Selected papers from the 39th Linguistic Symposium on Romance Languages (LSRL), 169186. Amsterdam: John Benjamins http://dx.doi.org/10.1075/cilt.315.10men.

Modesto, Marcello. 2000. "Null subject without 'rich' agreement”. In Mary Kato and Esmeralda Negrão (eds.), Brazilian Portuguese and the Null Subject Parameter, 147-174. Frankfurt and Madrid: Vervuert/Iberoamericana.

Montalbetti, Mario. 1984. After Binding: On the interpretation of pronouns. Doctoral dissertation. Cambridge, MA: Massachusetts Institute of Technology.

Montrul, Silvina. 2004. The Acquisition of Spanish. Amsterdam: John Benjamins.

Montrul, Silvina, Dias, Rejane. and Ana Thomé-Williams. 2009. "Subject expression in the non- native acquisition of Brazilian Portuguese". In Acrisio Pires and Jason Rothman (eds.), Minimalist Inquiries into Child and Adult Language Acquisition: Case Studies across Portuguese, 301-325. Berlin: Mouton DeGruyter. http://dx.doi.org/10.1515/9783110215359.2.301.

Nunes, Jairo. 2011. "The Copy Theory". In Cedric Boeckx (ed.), The Oxford Handbook of Linguistic Minimalism, 143-172. Oxford University Press, New York. http://dx.doi.org/10.1093/oxfordhb/9780199549368.013.0007.

Newmeyer, Frederick J. 2004 "Against a parameter-setting approach to language variation". Linguistic Variation Yearbook 4: 181-234. http://dx.doi.org/10.1075/livy.4.06new.

Ordóñez, Francisco and Antxon Olarrea. 2006. "Microvariation in Caribbean/Non-Caribbean Spanish Interrogatives”. Probus 18: 59-96. http://dx.doi.org/10.1515/probus.2006.003. 
Ortega-Santos, Ivan. 2008. Projecting subjects in Spanish and English. Doctoral dissertation. University of Maryland.

Perl, Matthias. 1998. "Introduction”. In Matthias Perland Armin Schwegler (eds.), América negra: panorámica actual de los estudios lingüisticos sobre variedades hispanas, portuguesas y criollas, 1-24. Madrid \& Frankfurt Iberoamericana-Vervuert.

Perl, Matthias and Armin Schwegler eds.). 1998. América negra: panorámica actual de los estudios lingüísticos sobre variedades hispanas, portuguesas y criollas. Madrid \& Frankfurt Iberoamericana-Vervuert.

Phinney, Marianne. 1987. "The pro-drop parameter in second language acquisition". In Thomas Roeper and Edwin Williams (eds.), Parameter setting, 221-238. Dordrecht: Reidel. http://dx.doi.org/10.1007/978-94-009-3727-7_10.

Pienemann, Manfred. 1998. Language Processing and Second Language Development: Processability Theory. Amsterdam: John Benjamins. http://dx.doi.org/10.1075/sibil.15.

Pienemann, Manfred. (ed.). 2005. Cross-linguistic Aspects of Processability Theory. Amsterdam: John Benjamins. http://dx.doi.org/10.1075/sibil.30.

Pollard, Carl and Ivan Sag. 1994. Head-Driven Phrase Structure Grammar. Chicago, IL: The University of Chicago.

Pollock, Jean-Yves. 1989. "Verb movement, Universal Grammar, and the structure of IP". Linguistic Inquiry 20: 365-424.

Preminger, Omer. 2014. Agreement and its failures. Cambridge, MA: MIT Press. http://dx.doi.org/10.7551/mitpress/9780262027403.001.0001.

Rizzi, Luigi. 1982. Issues in Italian syntax. Dordrecht: Foris. http://dx.doi.org/10.1515/9783110883718.

Rizzi, Luigi. 1996. "Residual verb second and the Wh-criterion". In Adriana Belletti and Luigi Rizzi (eds.), Parameters and Functional Heads, 63-90. Oxford: Oxford University Press.

Roberts, Ian and Anders Holmberg. 2010. "Introduction: parameters in minimalist theory". In Theresa Biberauer, Anders Holmberg, Ian Roberts and Michelle Sheehan (eds.), Parametric Variation: Null Subjects in Minimalist Theory., 1-57. Cambridge: Cambridge University Press. http://dx.doi.org/10.1017/cbo9780511770784.001.

Roberts, Ian. 1993. Verbs and diachronic syntax. Dordrecht: Kluwer. http://dx.doi.org/10.1007/978-94-011-2910-7.

Roeper, Thomas. 1999. "Universal bilingualism". Bilingualism: Language and Cognition 2: 169-184. http://dx.doi.org/10.1017/s1366728999000310.

Rothman, Jason and Roumyana Slabakova. 2011. "The Mind-Context Divide: On Acquisition at the Linguistic interfaces". Lingua 121: 568-576. http://dx.doi.org/10.1016/j.lingua.2011.01.003.

Sato, Yosuke and Chonghyuck Kim. 2012. "Radical pro drop and the role of syntactic agreement in Colloquial Singapore English”. Lingua 122 (8): 858873. http://dx.doi.org/10.1016/j.lingua.2012.02.006. 
Sessarego, Sandro. 2011. Introducción al idioma afroboliviano: Una conversación con el Awicho Manuel Barra. Cochabamba \& La Paz: Plural Editores.

Sessarego, Sandro. 2012. "Non-Creole Features in the Verb System of AfroHispanic Languages: New Insights from SLA Studies”. International Journal of Linguistics 4 (1): 146-157.

http://dx.doi.org/10.5296/ijl.v4i1.1415.

Sessarego, Sandro. 2013a. "Afro-Hispanic Contact Varieties as Conventionalized Advanced Second Languages". IBERIA 5 (1): 99-125.

Sessarego, Sandro. 2013b. Chota Valley Spanish. Madrid \& Frankfurt: Iberoamericana/Vervuert.

Sessarego, Sandro. 2014. "Afro-Peruvian Spanish in the Context of Spanish Creole Genesis". Spanish in Context 11 (3): 381-401.

http://dx.doi.org/10.1075/sic.11.3.04ses.

Sessarego, Sandro. 2015. Afro-Peruvian Spanish. Amsterdam: John Benjamins. http://dx.doi.org/10.1075/c1l.51.

Sessarego, Sandro. 2017a. "A Feature-Geometry Account for Subject-Verb Agreement Phenomena in Yungueño Spanish". In Juan Colomina-Almiñana (ed.). Contemporary Studies on Theoretical and Applied Linguistics of Spanish Variation. 165-185. Columbus, OH: Ohio State University Press.

Sessarego, Sandro. 2017b. "Chocó Spanish Double Negation and the Genesis of the Afro-Hispanic Dialects of the Americas". Diachronica. 34, 2: 219-252.

Sessarego, Sandro and Letânia Ferreira. 2016. "Spanish and Portuguese Parallels: Impoverished Number Agreement as a Vernacular Feature of two Rural Dialects". In Sandro Sessarego and Fernando Tejedo-Herrero (eds.), Spanish Language and Sociolinguistic Analysis, 283-304. Amsterdam: John Benjamins.

http://dx.doi.org/10.1075/ihll.8.12ses.

Saito, Mamoru. 2004. "Ellipsis and Pronominal Reference in Japanese Clefts". Studies in Modern Grammar 36: 1-44.

Silva, Gláucia V. 2001. Word order in Brazilian Portuguese. Berlin: De Gruyter. http://dx.doi.org/10.1515/9783110869552.

Sorace, Antonella. 2000. "Syntactic optionality in non-native grammars". Second Language Research 16: 93-102. http://dx.doi.org/10.1191/026765800670666032.

Sorace, Antonella. 2003. "Near-Nativeness". In Catherine J. Doughty and Michael H. Long (eds., The Handbook of Second Language Acquisition, 130-153. Oxford: Blackwell Publishers. http://dx.doi.org/10.1002/9780470756492.ch6.

Sorace, Antonella. 2004. "Native language attrition and developmental instability at the syntax-discourse interface: Data, interpretations and methods". Bilingualism: Language and Cognition 7: 143-145. http://dx.doi.org/10.1017/s1366728904001543.

Suñer, Margarita. 1983. "Proarb" Linguistic Inquiry 14: 188-191.

Tomioka. Satoshi 2003. "The semantics of Japanese null pronouns and its crosslinguistic implications". In Kerstin Schwabe and Susanne Winkler (eds.), The interfaces. Deriving and interpreting omitted structures, 321-339. Amsterdam: John Benjamins. 
http://dx.doi.org/10.1075/1a.61.16tom.

Toribio, Almeida J. 1993. "Lexical subjects in finite and non-finite clauses". Cornell Working Papers in Linguistics 11: 149-178.

Toribio, Almeida J. 2000. "Setting parametric limits on dialectal variation in Spanish". Lingua: International Review of General Linguistics 110 (5): 315-341. http://dx.doi.org/10.1016/s0024-3841(99)00044-3.

Villa-García, Julio. 2015. The Syntax of Multiple-que Sentences in Spanish: Along the Left Periphery. Amsterdam: John Benjamins. http://dx.doi.org/10.1075/ihll.2.

White, Lydia. 1985. "The pro-drop parameter in adult second language acquisition". Language Learning 35 (1): 257-277. http://dx.doi.org/10.1111/j.1467-1770.1985.tb01014.x.

White, Lydia. 1986. "Implications of parametric variation for adult second language acquisition: An investigation of the 'pro-drop' parameter". In Vivian Cook (ed.), Experimental approaches to second language acquisition, 55-72. Oxford: Pergamum.

White, Lydia. 1992. "Subjacency violations and empty categories in L2 acquisition". In Helen Goodluck and Michael Rochement (eds.), Island Constraints, 445-464. Dordrecht: Kluwer. http://dx.doi.org/10.1007/978-94-017-1980-3_17.

White, Lydia. \& Alan Juffs. 1998. "Constraints on wh-movement in two different contexts of non-native language acquisition: competence and processing". In Suzanne Flynn, Gita Martohardjono and Wayne O'Neil (eds.), The Generative Study of Second Language Acquisition, 111-129. Mahweh, NJ: Lawrence Erlbaum.

Yang, Charles D. 2002. Knowledge and learning in natural language. Oxford: Oxford University Press.

http://dx.doi.org/10.1007/springerreference_302605. 